\title{
Participation Of Beekeeping Group On Forest Sustainability In Muara Enim Regency, South Sumatra Province
}

\author{
Beni Rahmad $^{1)}$, Nurhayati Damiri ${ }^{2 *}$, Mulawarman ${ }^{2)}$ \\ 1) Student at Environmental Management, Postgraduate Program, Sriwijaya University. \\ ${ }^{2)}$ Lecturers at the Department of Agriculture, Faculty of Agriculture, Sriwijaya University \\ *Corresponding Author: nurhayatidamiri@gmail.com
}

Article history

$\begin{array}{llll}\text { Received } & \text { Received in revised form } & \text { Accepted } & \text { Available online } \\ \text { 04 March 2021 } & \text { 03 April 2021 } & \text { 28 April 2021 } & \text { 29 April 2021 }\end{array}$

04 March $2021 \quad 03$ April 2021

\begin{abstract}
The dynamic nature of forest habitats is currently influenced by the impact of many disturbing factors, including fire, grazing, area fragmentation, land use conversion and invasion of communities outside forest areas. Fire and smoke from forest and land fires have a profound effect in producing landscape changes that also affect the regeneration of associated vegetation and animals. This study aimed to: (1) determine the participation of the members of the beekeeper group in preserving the Subanjeriji production forest, in Muara Enim Regency, South Sumatra Province and (2) to determine the attitudes, knowledge and perceptions of beekeepers on the relationship between beekeeping and forest suistainibility. The research was conducted using a survey method with a qualitative approach. The results showed that beekeepers known the suistainability of forest areas that affect the success of beekeeping (80\%), so that $60 \%$ of beekeepers understand very well that forest and land fires can reduce bee populations and reduce the amount of honey bee. Most of beekeepers also understand that the existence of forest plants is very beneficial to support honey production, so that the majority beekeepers are involved in land enrichment efforts with woody plants and most choose Multi Purpose Tree Species (MPTS) plants that produce fruit.
\end{abstract}

Keywords: Participation, Beekeepers, Beekeeping, Sustainibility, HP Subanjeriji

Abstrak: Sifat dinamis habitat hutan saat ini dipengaruhi oleh dampak dari banyak faktor-faktor pengganggu, termasuk kebakaran, penggembalaan, fragmentasi kawasan, praktik alih fungsi penggunaan lahan dan invasi masyarakat luar kawasan hutan. Api dan asap dari kebakaran hutan dan lahan memiliki pengaruh yang sangat besar dalam menghasilkan perubahan bentang alam yang turut mempengaruhi regenerasi vegetasi dan fauna terkait. Penelitian ini bertujuan untuk (1) mengetahui partisipasi anggota kelompok peternak lebah madu dalam menjaga kelestarian hutan produksi (HP) Subanjeriji, di Kabupaten Muara Enim, Provinsi Sumatera Selatan dan (2) untuk mengetahui sikap, pengetahuan dan persepsi peternak lebah madu terhadap hubungan antara budidaya lebah madu dan keberadaan hutan. Penelitian dilaksanakan dengan metode survei dengan pendekatan kualitatif. Hasil penelitian menunjukkan peternak lebah madu memahami keberadaan kawasan hutan yang mempengaruhi keberhasilan budidaya lebah madu (80\%), sehingga 60\% peternak sangat memahami kebakaran hutan dan lahan dapat mengurangi populasi lebah dan mengurangi jumlah hasil panen madu. Sebagian besar peternak juga memahami keberadaan tanaman hutan sangat bermanfaat untuk mendukung produksi madu, sehingga mayoritas peternak terlibat dalam upaya pengkayaan lahan dengan tanaman berkayu dan sebagian besar memilih tanaman jenis Multi Purpose Tree Species (MPTS) yang menghasilkan buah-buahan.

Kata kunci: Partisipasi, Peternak, Budidaya Lebah Madu, Lestari, HP Subanjeriji

\section{Introduction}

The results of identification by the Central Bureau of Statistics (2014) showed that in Indonesia 8.643.228 household heads are living inside and around forest areas and as many as 242.866 households practice shifting cultivation $(2,81 \%)$. Communities who live in and around forest areas are more dependent on forest products than communities outside forest areas. This can be seen from the higher percentage of the community's main source of income in the forestry sub-sector inside and around forest areas when compared to communities outside forest areas [1].The dynamic nature of forest habitats is currently influenced by the impact of many disturbing factors, including forest-fire, grazing, area fragmentation, land use conversion practices and invasion of communities outside forest areas. Fire and smoke from forest and land fires have a profound effect in producing landscape changes that also affect the regeneration of associated vegetation and animals [2]. The forest fires also affect the stages of growth or development plant, for example the abundance of hardwood trees beneath the United States pine forest stands decreased due to the high intensity of fires with annual fires causing deaths $85 \%$ of the stands, while only $59 \%$ of the plants that died twice a year [3].

Honey-producing bees are closely related to the existence of forests. Flowers from trees that grow 
in the forest provide food for honey bees and the trees physically provide shelter for honey bee colonies. The forests and beekeeping existence have a long history and have been applied since decades ago, but are rarely integrated or systematically studied. Integrated tree planting, such as in agroforestry systems, can be designed to support feed availability and increase honey production [4]. Cultivating or raising bees can be an alternative to additional income for communities around forest areas, because they do not require feed procurement costs (zero feed cost). Honey bee can be harvested once in 2 weeks or the equivalent of seven months in a year [5] As a comparison, if the farmer has 100 cultivation boxes (stup), then in one productive season they can produce three to four tons of honey per year.

Subanjeriji Production Forest is located in Muara Enim Regency, South Sumatra Province, whose concession license is owned by PT. Musi Hutan Persada, which is engaged in the cultivation of acacia plants as raw material for making pulp and paper. To reduce the rate of degradation and land use change in forest areas, one of the community empowerment programs is through bee-keeping. The Sari Puspa Forest Farmers Group (KTH) is a group of honey beekeepers engaged in honey beekeeping through the stup system and placing the stup in the Subanjeriji Production Forest area which is domiciled in Gunung Megang District, Muara Enim Regency, South Sumatra Province. KTH Sari Puspa member beekeepers have a great dependence on the existence of forests.

The high dependence of beekeepers on forest areas encourages honey beekeepers to continue to preserve forests and prevent forest destruction, resulting in a strong symbiotic relationship between beekeepers and the existence of forest areas, the purpose of this study was to determine the attitudes, knowledge and perceptions of beekeepers regarding the relationship between forest sustainability and the development of honey bee cultivation and to determine the participation of beekeepers in efforts to enrich woof source plants as part of forest conservation efforts.

\section{Materials and Methods}

The study has been conducted through direct observation of the study area and interviews with each beekeeper in the research area. The taken samples were 20 beekeepers who are members of the Forest Beekeepers Group $(K T H)$ Sari Puspa who cultivate bees in the forest area. The study used descriptive qualitative research. The qualitative research is a research procedure that produces descriptive data in the form of speech or writing and the behavior of the people being observed [6]. The purpose of qualitative research is to understand social phenomena or symptoms by focusing more on a complete picture of the phenomena being studied [7]. Respondens would be interviewed regarding their attitudes and perceptions such as the choice of techniques in land clearing, the impact of forest degradation on reduced honey productivity and also about the efforts of each beekeeper to plant crops as part of the area enrichment effort.

Secondary data were obtained by direct interviews with beekeepers and policy makers such as village heads, concession holders, field extension officers and other parties deemed relevant to the research data. Geographical information on the location of the study was showed at Figure 1:

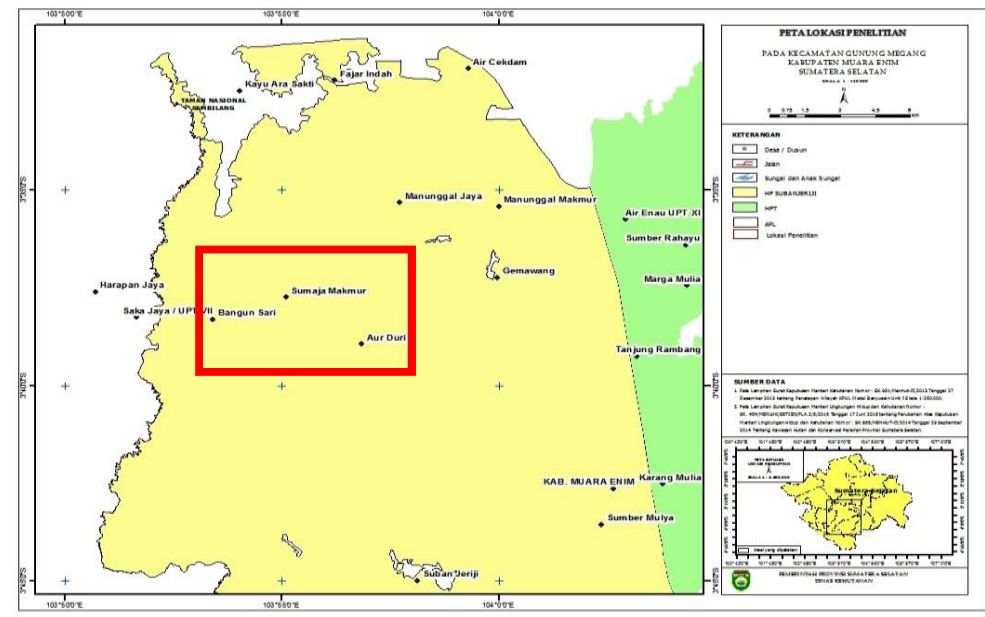

Source : Dinas Kehutanan Sumsel (2020)

Figure 1. Research location map

The types of data taken in this study were primary and secondary data. The data taken including the condition of the area, the ecosystem, human resources, development activities in the research area 
and management policies, characteristics of forest beekeepers, the level of community participation in community empowerment programs, the level of program success [8]. The data analysis used for the farmer group census method was scaling (Modified Likert Scale). To scale with this method, each respondent will be asked to state his answer to the statements in the questionnaire in the five answer categories that have been provided, namely as follows: a. Strongly disagree, b. Disagree, c. Neutral, d. Agree, e. Strongly agree.

From the distribution of respondens answers to the questionnaire, it will be concluded to what extent the perceptions and attitudes of beekeepers related to the existence of forests to the development of honey bee cultivation were presented in Table 1.Therefore, the ideal score to determine how much understanding, perceptions and attitudes of members of the farmer group regarding the existence of the area towards honey bee cultivation can be determined. To get clearer and more detailed results, this study used a Likert scale analysis [8]. Likert scale was used to measure attitudes, opinions and perceptions of a person or group about social events or symptoms.

Table 1. Scoring For Each Category Of Perceptions And Attitudes

\begin{tabular}{lcc}
\hline Answer Options & \multicolumn{2}{c}{ Score of each statement } \\
\cline { 2 - 3 } & Positive statement & Negative statement \\
\hline Strongly Disagree /Very Understand & 1 & 5 \\
Disagree/Understand & 2 & 4 \\
Doubtful & 3 & 3 \\
Agree/ Understand & 4 & 2 \\
Strongly Agree / Understand & 5 & 1 \\
\hline
\end{tabular}

Source: Riduan and Kuncoro (2006)

Information :

Score $=\frac{\text { Total Score }}{y} \times 100 \%$

$\mathrm{Y}=$ The highest Likert score $\times$ the number of respondents

Table 2. The Ideal Score For The Level Of Understanding, Perception And Attitude

\begin{tabular}{ll}
\hline Score Range (\%) & Perception and Understanding Category Attitude \\
\hline $0-19.99$ & Strongly disagree / totally don't understand \\
$20-39.99$ & Disagree / don't understand \\
$40-59.99$ & Simply understanding / neutral \\
$60-79.99$ & Agree / understand \\
$80-100$ & Very agree / very understand \\
\hline
\end{tabular}

Source: Riduan and Kuncoro (2006)

\section{Result and Discussion}

3.1. The attitude and knowledge of beekeepers on the forest sustainability and their relationship with honey bee cultivation
The attitude and knowledge of beekeepers on the forest sustainability for the sustainability of honey bee cultivation was presented at Table 3:

Table 3. The Attitude And Knowledge Of Beekeepers Regarding The Urgency Of Forest Sustainability For Beekeeping

\begin{tabular}{llcc}
\hline No & \multicolumn{1}{c}{ Indicator } & Number of Respondent & Score (\%) \\
\hline 1 & $\begin{array}{l}\text { The existence of forest areas greatly affects the success of } \\
\text { beekeeping }\end{array}$ & 20 & 80 \\
2 & $\begin{array}{l}\text { Knowing forest and land fires can reduce bee populations and } \\
\text { reduce the amount of honey production }\end{array}$ & 20 & 85 \\
3 & $\begin{array}{l}\text { Knowing the presence of plant stands in a forest area greatly } \\
\text { affects honey production }\end{array}$ & 20 & 88 \\
4 & $\begin{array}{l}\text { Always enrich the land by planting woody plants as a woof } \\
\text { source of beekeeping } \\
\text { The type of plant that is mostly grown as a woof source is the } \\
\text { multipurpose plant }\end{array}$ & 20 & 80 \\
\hline
\end{tabular}

Based on the Table 3, it can be seen the perceptions of beekeepers on the forest sustainability 
for the sustainability of beekeeping. $80 \%$ of beekeepers agree that the existence of forest areas greatly affect the success of honey beekeeping. So that beekeeper agree that efforts to degradate forest areas will only harm the honey beekeeping they are developing. $60 \%$ of beekeepers had a well understanding related to the relationship between forest and land fires that will have a negative impact in the form of a reduction in the bee population and decreasing the amount of honey production. Meanwhile, related to the presence of plants in the area that affect honey production, $85 \%$ of beekeepers strongly agree, so that $98 \%$ of beekeepers enrich their land with woody plant species likes Acacia mangium, Acacia crassicarpa, Calliandra calothyrsus, Albizzia falcataria, etc . $80 \%$ of beekeepers choose fruit-producing multipurpose plant likes Mangifera indica, Dimocarpus longan, Nephelium lappaceum, and many more as the main choice in land enrichment.

Honey beekeepers were active in land enrichment efforts by planting other types of plants besides rubber and oil palm. The forms of woof source plant enrichment can be seen at Figure 2 Community Participation in forest suistainability:
Figure 2 showed the active role of beekeepers in land enrichment efforts. Subanjeriji production forest area used unproductive land as "Biodiversity Development Land", or an enrichment garden specifically planted with honey bee woof sources from forestry plants, multipurpose plant and other flowering plants. The placement of the stup in the honey bee cultivation location followed the planting pattern of acacia plants. Of the various types of plants known to be a source of food for bees is acacia. Acacia is believed to be a plant frequented by bees and was able to provide nectar throughout the year, so that the presence of acacia in Subanjeriji production forests greatly affects the amount of honey production. Acacia plants can emit nectar drops near the stalks of the leaf base and almost all acacia leaf bases emit nectar throughout the year so that it can be a very potential and sustainable source of nectar for bees [9]. The nectar from acacia plants is a potential nectar as a source of feed for honey bees. Furthermore, it was reported that honey production from several species of acacia plants as shown at Table 4 [10]:
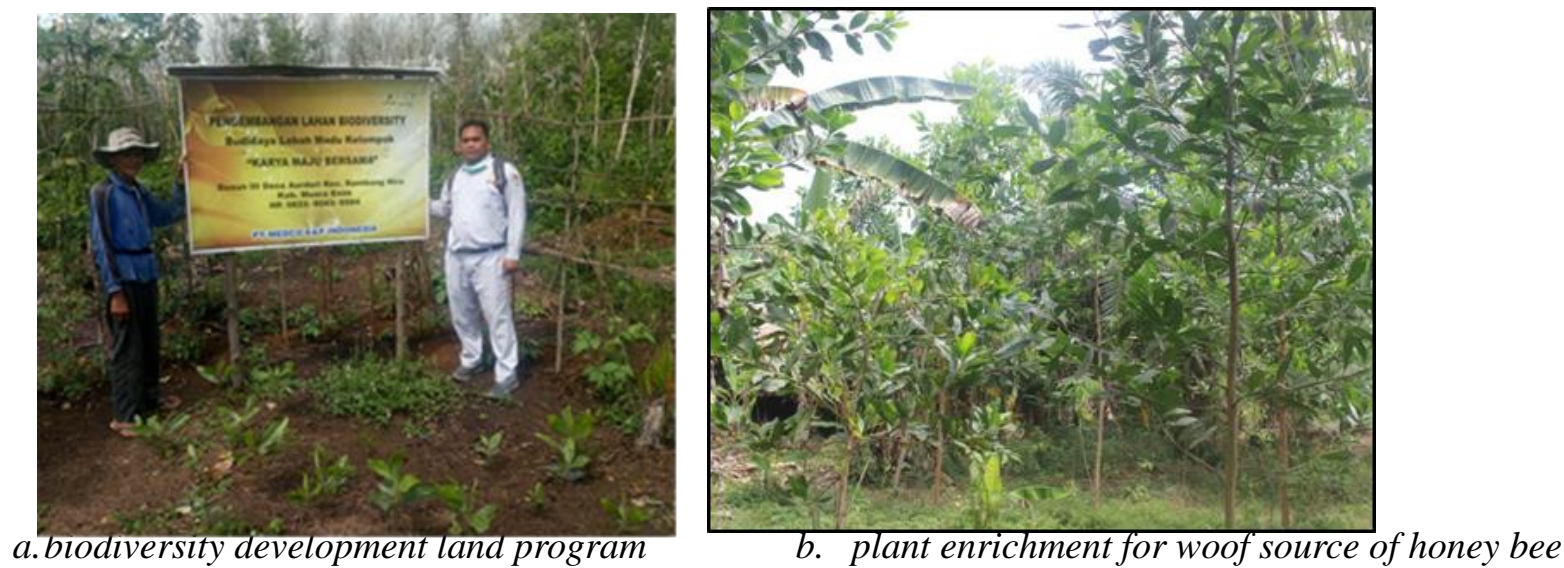

Figure 2. Community Participation in Forest Suistainability

Table 4. Honey Production From Several Species Of Acacia Plants

\begin{tabular}{llc}
\hline No & Species of acacia plants & Honey production $(\mathrm{kg} / \mathrm{ha})$ \\
\hline 1. & Acacia asak & 110 \\
2. & Acacia ehrenbergiana & 443 \\
3. & Acacia etbaica & 51 \\
4. & Acacia gerrardii & 511 \\
5 & Acacia johnwoodii & 625 \\
6. & Acacia aoefota & 120 \\
7. & Acacia origena & 325 \\
8. & Acacia tortilis & 223 \\
\hline
\end{tabular}


This laying system can be said to be a semi-grazing system (angon), because to fulfiil the needs of bees for nectar and pollen elements, beekeepers move the stup to the acacia plantation. The honey bee technology of semi-grazing system is a new innovation in refinement of the less productive traditional honey bee cultivation technology. This technology is a unity of several technologies concerning the means and tools used for action in farming in a better and more profitable direction. This technology includes technology for locating, obtaining colonies, moving and placing colonies, techniques for adding new combs, joining colonies, catching queens, harvesting and post-harvesting [11]. This is based on the knowledge that in order to obtain large amounts of honey production, a source of nectar must be available in large quantities. So that the ownership of the stup with a large number and the income from the honey which is large enough motivates the beekeepers to actively develop their business with innovative methods. This was in line with the research with the title Study of Adoption of Honeybee Cultivation Technology with Angon System and Its Contribution to Household Income of Beekeepers in Grinsing District, Batang Regency, with one conclusion that there was a strong enough relationship between

\subsection{Participation Of Beekeepers In Preserving The Environment And Forests} The attitude and knowledge of KTH Sari Puspa ownership of stup and the level of adoption of honey bee cultivation technology with the free-range system [11]. Therefore, it can be concluded that the more the number of stup the beekeepers has, the more honey products the beekeeper can get, and the greater the capital invested in the business, the greater the risk he will bear in the event of a harvest failure. Therefore, beekeepers will be increasingly active in seeking and trying new innovations that are considered better and more efficient, and which can provide higher yields. Cultivation locations outside forest areas, honey bee were placed near rubber or oil palm plantations, and in areas enriched with multipurpose plants and other types of plants. In addition to make it easier for bees to reach the woof source, this was also to make it easier for beekeepers to supervise the bee colony.

Honey bees are largely determined by the presence of a source of feed. If the source of feed is reduced, the productivity of honey will also decrease, including the risk of escaping the honey bee colony [6] On the other hand, beekeepers also have to know the types of plants to be planted as woof source, which can be available throughout the year with different flowering seasons. The income from honey beekeeping is quite promising for the living needs of beekeepers.

member honey bee beekeepers in preserving the environment and forests was presented at Table 5:

Table 5. The Attitude And Knowledge Of KTH Sari Puspa Member In Preserving The Environment And Forests

\begin{tabular}{llcc}
\hline No & \multicolumn{1}{c}{ Indicator } & Number of respondent & Score (\%) \\
\hline 1 & $\begin{array}{l}\text { The chosen method of cleaning and land preparation } \\
\text { using mechanical devices. }\end{array}$ & 20 & 60 \\
2 & $\begin{array}{l}\text { Knowing the negative impacts caused by land } \\
\text { clearing by burning. }\end{array}$ & 20 & 60 \\
$\begin{array}{l}\text { Choosing a pesticide according to the type of pest } \\
\text { and low toxicity. }\end{array}$ & $\begin{array}{l}\text { Knowing the negative effects of pesticides in addition } \\
\text { to causing health problems can also pollute the } \\
\text { environment }\end{array}$ & 70 \\
\hline
\end{tabular}

Based on the results of the research, the most preferred method of cleaning and land preparation was by using mechanical devices. The rest were clearing the land by slashing and then burning them and a small proportion chose to use herbicides. The attitude of most beekeepers was based on the knowledge of some growing weeds, there were several types of weeds that are often visited by bees for nectar and pollen. Others argue when clearing the land by burning it will have an impact on the migration of bees cultivated in the hive. Another impact of forest fires was the loss of plants in forest areas, which has an impact on the availability of a woof source for honey bees.

The results of research in Sumatra in 4 (four) provinces, namely Lampung, Jambi, South Sumatra and Riau, showed that forest and land fires occur due to: (1) use of fire for land clearing, (2) use of fire as a weapon in resolving land conflicts, (3) accidental spread of fire, and (4) extraction of natural resources and forest degradation [12]. Generally, forest and land fires that occur have many impacts on biological biodiversity (flora and fauna). On a global basis, forest fires were a significant source of carbon emissions and contribute to global warming which results in 
decreasing biological biodiversity. In addition, in the local or regional context, forest fires caused forest biomass stocks, the hydrological cycle, plant physiological activity (death and decrease in plant photosynthetic activity) and animals as well as human and animal health [9]. Besides, almost all beekeepers know that, the activity of clearing land by burning will have a negative impact on the environment. A long dry season, which is usually accompanied by high temperatures and low humidity, will easily trigger larger fires. The negative impacts of forest and land fires on vegetation include: (1) high fire intensity can kill all saplings, lianas, and trees. (2) Causes wounds and stress on trees so they are prone to pests and diseases. (3) Stand increment decreases because many trees are stressed or stands are sparse. (4) Wounds in trees caused by fire can cause permanent disabilities, so the quality of the wood decreases, damage to rejuvenation or young plants and decreased plant diversity. (5) Influencing vegetation succession patterns; after fires, natural regeneration begins with pioneer plants (intolerant), then semi-tolerant and tolerant plants then become climax forests. (6) If many trees die, other forest functions such as water management and soil protection will be disturbed [13].

Even in choosing pesticides, beekeepers tend to have the same attitude. Most beekeepers choose pesticides according to the type of pest and have low toxicity. Even some beekeepers have started to develop and use natural pesticides that are more environmentally friendly. This is in line with the knowledge of beekeepers that the negative impact of pesticides in addition to causing health problems can also pollute the environment. Especially for beekeepers, they also know that some types of bees are not resistant to pesticides and may contaminate the honey they produce. The effect of pesticide use occurs in colonies, pesticide contamination in hive products is estimated when honey bee colonies perish due to exposure to pesticides. Colony mortality is often accompanied by residues per million (ppm) in wax, beebread, honey and dead bee samples. Social bees are very sensitive to pesticide contamination so they do not come to the flower of seasonal agricultural crops contaminated by pesticides [14]. The study about Diversity and Abundance of Social Bees (Apidae) in the Pesticide-Applied Seasonal Crops in West Java concluded that the diversity and abundance of social bees visiting pesticide-applied seasonal agricultural crops in the lowlands of Dramaga and the highlands of Lembang was low [15].

Perceptions, attitudes and knowledge that are quite good that are owned by beekeepers, can be used

\section{References}

[1] H. Simon, Pengelolaan Hutan Bersama Rakyat as a basis for developing knowledge of beekeeping towards a better direction. The motivation to develop a honey bee cultivation business is not only limited to economic orientation, but also as part of environmental preservation and to participate in maintaining the sustainability of the existence of forest areas. Because in knowledge, beekeepers know that between forests, bees and beekeepers there is a mutually beneficial symbiotic relationship. The perceptions of beekeepers in maintaining forest sustainability are in line with the results of a study from the EC-Indonesia Forest Law Enforcement, Governance and Trade (FLEGT) Support Project (2008) regarding the perceptions of Dayak indigenous people in West Kalimantan Province towards the forests in their environment, among others: (1) their presence in an area is not on their own accord but because of inheritance from their ancestors. It makes them feel entitled to manage the natural resources around their residence. (2) They are very dependent on timber and non-timber forest products to meet their primary needs, clothing, and boards, so that in order for them to live well and eat, they will try to conserve the forest [16]. With this perception, it can be concluded that in fact the existence of the community around the forest area is basically not a forest destroyer but a forest custodian.

\section{Conclusion}

Beekeepers have good perceptions, attitudes and knowledge. Most beekeeper understand very well that the existence of forest areas greatly affects the success of beekeeping, so that most beekeepers understand very well that forest and land fires can reduce bee populations and reduce the amount of honey harvested. In addition, most beekeepers also understand that the existence of forest plants is very useful to support honey production, so that the majority of beekeepers participate in efforts to conserve the environment and forest areas by enriching land with woody plants and most of them choose multipuprpose plant that produce fruit.

\section{Acknowledgement}

Our gratitude goes to Mr. Suryadin as chairman of the Sari Puspa Forest Farmers Group (KTH) who has provided support during the implementation of research and data collection and also to Mr. Bustam and Mr. Darim and also for beekeepers who have provided information in this research.

(Cooperative Forest Management). Yogyakarta : BIGRAF Publishing. 2008. 
[2] E. Monique, Rocca, P. M. Brown, L. H. MacDonald, C. M. Carrico, "Climate change impacts on fire regimes and key ecosystem services in Rocky Mountain forests". Forest Ecology and Management, vol 327, pp. 290-305, 2014.

[Online].

Available:https://www.sciencedirect.com/scienc e/article/pii/S0378112714002308

[3] J. P. Kimmins, Forest Ecology a Foundation for Sustainable Forest Management and Environmental Ethics in Forestry. New Jersey: Prentice Hall. 2004.

[4] D. B. Hill, T. C. Webster, "Apiculture And Forestry (Bees And Trees)". Agroforestry Systems, vol 29, pp. 313-320, 1995. [Online]. Available: https://doi.org/10.1007/BF00704877

[5] D. T. H. Sihombing, Ilmu Ternak Lebah Madu. Yogyakarta: Gadjah Mada University Press. 2005.

[6] M. Mulyono, T. Susdiyanti, B. Supriono, "The Study of Availability Of Local Honey Bees Feed". J. Nusa Sylva, vol 15, no.2, pp. 18-26, 2015. [Online]. Available: http://www.ejournalunb.ac.id/index.php/JNS/art icle/view/3

[7] Rahardjo, Pengantar Sosiologi Pedesaan Dan Pertanian. Yogyakarta: Gadjah Mada University Press. 2010.

[8] F. Ramdani, P. B. P. Panjaitan, K. Bintani, "Persepsi Kelompok Tani Terhadap Program Pemberdayaan Masyarakat (Budidaya Lebah Madu Apis mellifera) Di Tahura Ir. H. Djuanda Bandung". J. Nusa Sylva, vol. 14, no.2, pp. 33-42, 2014. [Online]. Available: http://ejournalunb.ac.id/index.php/JNS/article/vi ew/152

[9] Agussalim, A. Agus, N. Umami, I. G. S. Budisatria, "Variasi Jenis Tanaman Pakan Lebah Madu Sumber Nektar Dan Polen Berdasarkan Ketinggian Tempat Di Yogyakarta". Buletin Peternakan, vol. 41, no.4, pp. 448-460, 2017. [Online]. Available: https://pdfs.semanticscholar.org/f2a0/f48705af2 0642d5745438474a84a10bd1f45.pdf

[10] N. Adgaba, A. Al-Ghamdi, Y. Tadesse, A. Getachew, A. M. Awad, M. J. Ansari, A. A. Owayss, S. E. A. Mohammed, A. S. Alqarni, "Nectar secretion dynamics and honey production potentials of some major honey plants in Saudi Arabia". Saudi Journal of Biological Sciences, vol. 24, pp. 180-191, 2017. [Online]. Available: https://www.sciencedirect.com/science/article/pi i/S1319562X16300298

[11] E. Sriningsih, S. Widarni, "Kajian Adopsi Teknologi Budidaya Lebah Madu Sistem Angon
Dan Sumbangannya Terhadap ${ }^{\text {ojs.pendapri.acia }}$ Rumah Tangga Petani Di Kecamatan Grinsing Kabupaten Batang”. J. Pembangunan Pedesaan, vol. 7, no. 1, pp. 32-42, 2007. [Online]. Available:

http://jurnal.lppm.unsoed.ac.id/ojs/index.php/Pe mbangunan/article/view/142

[12] R. Nasi, R. Dennis, Meijaard, E. G. Applegate, P. Moore, "Forest Fire and Biological Diversity". Unasylva-FAO, pp.36-40, 2002.

[13] D. Wida, F. D. Tuheteru, "Forest Fire Impact on the Growth of Vegetation". Tekno Hutan Tanaman, vol.3, no.1, pp. 27-32, 2010. [Online]. Available:

https://www.forda-mof.org/files/Tekno_HT_3.1. 2010-5.Wida_Darwiati_n_Faisal_Danu.pdf

[14] N. Desneux, A. Decourtye, J. M. Delpuech, "The sublethal effects of pesticides on beneficial arthropods". Annu. Rev. Entomol, vol.52, pp. 81-106, 2007. [Online]. Available: https://www.annualreviews.org/doi/abs/10.1146/ annurev.ento.52.110405.091440

[15] S. Kahono, Erniwati, "Keragaman Dan Kelimpahan Lebah Sosial (Apidae) Pada Bunga Tanaman Pertanian Musiman Yang Diaplikasi Pestisida Di Jawa Barat". Berita Biologi, vol.13, no.3, pp. 231-238, 2014. [Online]. Available: https://e-journal.biologi.lipi.go.id/index.php/beri ta_biologi/article/view/660

[16] Z. Qalbi, Iskandar, S. Siahaan, "Partisipasi Masyarakat Desa Tunggul Boyok dalam Melestarikan Pohon Kempas (Kompassia Sp) sebagai Tempat Bersarang Lebah Madu di Desa Tunggul Boyok Kecamatan Bonti Kabupaten Sanggau". J. Hutan Lestari, vol 3, no.4, pp.538-542. 2015. [Online]. Available: https://jurnal.untan.ac.id/index.php/jmfkh/article /view/12869 